\title{
Diplarche and Menziesia transferred to Rhododendron (Ericaceae)
}

\section{L.A. Craven ${ }^{1}$}

Key words

Diplarche

Ericaceae

Menziesia

Rhododendron

taxonomy

\begin{abstract}
The genera Diplarche and Menziesia have been shown to be nested in Rhododendron based upon cladistic analyses of DNA data. Morphologically, the differences between Diplarche and Menziesia are not so great that their inclusion in Rhododendron is inappropriate and the species of these two genera are formally transferred to Rhododendron. The following new names are proposed: Rhododendron benhallii, $R$. chamberlainii, $R$. goyozanense, $R$. $\times$ kamatae, $R$. katsumatae, $R$. kroniae, $R$. menziesii, R. menziesii subsp. glabellum, $R$. multiflorum, $R$. multiflorum forma bicolor, $R$. multiflorum forma brevicalyx, $R$. multiflorum var. purpureum, $R$. pentandrum, $R$. pilosum, R. sophistarum, R. yakushimense.
\end{abstract}

Published on 16 March 2011

\section{INTRODUCTION}

Rhododendron $\mathrm{L}$. is a large and morphologically diverse genus and, due to its showy flowers, is often cultivated as ornamental plants for the garden or for sale as flowering potted plants. Plant breeders have been active in hybridising programs aimed at development of novel cultivars and there are many named cultivars available; the International Register and Checklist for Rhododendron cultivars that is maintained by the Royal Horticultural Society, United Kingdom, currently contains about 25500 names (A. Leslie, pers. comm.). As far as I am aware, the only successful hybridisations, i.e., those resulting in progeny that grow reasonably well and produce flowers (whether or not the plants sexually are fully functional), have been obtained from crosses within Rhododendron. Consequently, reports of experimental intergeneric hybridisation between Menziesia Sm. and Rhododendron (Handa et al. 2003, 2006, Kita et al. 2005) stimulated me to consult the literature to learn more about the relationships between these two genera.

Menziesia and Rhododendron were placed, with Diplarche Hook.f. \& Thomson and Therorhodion Small, in the tribe Rhodoreae by Stevens et al. (2004). Therorhodion is often placed in Rhododendron (Spethmann 1987, Chamberlain et al. 1996, Kurashige et al. 2001, Fang et al. 2005, Goetsch et al. 2005) which placement is supported by cladistic analysis of molecular data (Kurashige et al. 2001, Goetsch et al. 2005), although one could argue for separate recognition as it is sister to all other Rhododendron clades. Menziesia has been included in several molecular systematic studies (Goetsch et al. 2005: $M$. ciliicalyx Maxim. and M. ferruginea Sm., Kurashige et al. 2001: M. multiflora Maxim.). In Goetsch et al. (2005) the genus nested in a clade that includes species of subg. Candidastrum Franch., sect. Sciadorhodion Rehder \& Wilson (incl. R. schlippenbachii Maxim.) and $R$. vaseyi A.Gray. In Kurashige et al. (2001, Fig. 3), M. multiflora forms a clade with $R$. schlippenbachii and $R$. quinquefolium Bisset \& S.Moore. Goetsch et al. (2005) classify the clade that includes Menziesia as sect. Sciadorhodion. Diplarche multiflora Hook.f. \& Thomson was

\footnotetext{
${ }^{1}$ Australian National Herbarium, CPBR, CSIRO Plant Industry, GPO Box 1600, Canberra, ACT 2601, Australia; e-mail: Lyn.Craven@csiro.au.
}

included in phylogenetic studies of Ericaceae by Kron et al. (2002) and in an analysis of matK data (Kron et al. 2002, Fig. $4 \mathrm{~A}$ ) it formed a clade with $R$. stamineum Franch. An analysis of rbcL data (Kron et. al. 2002, Fig. 5A) does not give an indication of the position of Diplarche as the tree was poorly resolved, however their combined analyses of matK and $r b c \mathrm{~L}$ data from smaller sample sets (Kron et al. 2002, Fig. 6, 7) resulted in Diplarche forming a clade with Menziesia and Rhododendron. The number of Rhodoreae species in each of the reduced sample sets was too small ( 7 species in Fig. 6 and 5 species in Fig. 7) for the position of Diplarche within Rhododendron to be clear. Its association with $R$. stamineum in the matK analysis suggests that perhaps it may belong in, or near, subg. Choniastrum (Franch.) Drude, but this will require testing using a greater number of species from this subgenus together with a strong sampling of species from the other higher-level taxa of Rhododendron, and with datasets preferably drawn from both $\mathrm{n}$ - and cpDNA. Chamberlain et al. (1996) list 19 species in subg. Choniastrum (as sect. Choniastrum) and three species of the subgenus were included in the studies of Goetsch et al. (2005) but these authors did not sample Diplarche in their $r p b 2$ studies.

The morphological differences between Diplarche, Menziesia and Rhododendron are not so great that the molecular evidence supporting inclusion of the two first-named genera in Rhododendron should be rejected. Given the dwarf habit and microphyllous nature of plants of Diplarche (Fang et al. 2005), the lack of perulae may be the result of the developing reproductive or vegetative growth being adequately protected by the dense foliage and pulvinate habit. In contrast, in Rhododendron the plant is often relatively large and the buds may be more exposed to the vagaries of climate; perulae presumably provide the developing organs with protection from cold and/or desiccation. Anther dehiscence by slits occurs in all three genera although slits are less common in Rhododendron in which dehiscence by pores is the more common condition. Viscin threads occur among the pollen grains in Rhododendron and presumably play a role in pollen removal from the anthers and its adhesion to pollinators. Menziesia is reported by Stevens et al. (2004) and Kita et al. (2005) to lack viscin threads although Copeland (1943: 543) reports them to occur. Stevens et al. 
(2004: 162) also differentiate Menziesia from Rhododendron by capsule shape, it being subspheroidal in Menziesia and longer than wide in Rhododendron. The capsule in Diplarche is spheroidal also (Fang et al. 2005). However, the capsule in Rhododendron may be very short, e.g., R. maddenii Hook.f., in which species the capsule is about as long as wide, and this character may not be significant for classification. In Diplarche, the antesepalous stamens are epipetalous and this may be an autapomorphy for the taxon with respect to Menziesia and Rhododendron.

In the following section, those taxa of Diplarche and Menziesia accepted in Fang et al. (2005) and Yamazaki (1993), respectively, together with three North American Menziesia taxa, are transferred to Rhododendron.

\section{TAXONOMY}

\section{Rhododendron sect. Sciadorhodion Rehder \& Wilson}

Menziesia Sm. (1791) t. 56

\section{Rhododendron benhallii Craven, nom. nov.}

Replaced synonym: Andromeda ciliicalyx Miq., Ann. Mus. Bot. LugdunoBatavi 1 (1863) 30. - Menziesia ciliicalyx (Miq.) Maxim. (1871) 10.

Note - A new name is required as the epithet ciliicalyx is pre-empted in Rhododendron by $R$. ciliicalyx Franch. The new name honours Benjamin D. Hall (1932-), University of Washington, whose studies into the evolutionary relationships of several groups of organisms, including Rhododendron, have greatly informed taxonomists.

2. Rhododendron goyozanense (M.Kikuchi) Craven, comb. nov.

Basionym: Menziesia goyozanensis M.Kikuchi, J. Jap. Bot. 37 (1962) 355.

3. Rhododendron $\times$ kamatae (Mochizuki) Craven, comb. nov.

Basionym: Menziesia $\times$ kamatae Mochizuki, J. Phytogeogr. Taxon. 29 (1981) 108.

4. Rhododendron katsumatae (M.Tash. \& H.Hatta) Craven, comb. nov.

Basionym: Menziesia katsumatae M.Tash. \& H.Hatta, Bot. Mag. (Tokyo) 99 (1986) 29.

\section{Rhododendron kroniae Craven, nom. nov.}

Replaced synonym: Menziesia purpurea Maxim., Bull. Acad. Imp. Sci. SaintPétersbourg 11 (1867) 431.

Note - A new name is required as the epithet purpureum is pre-empted in Rhododendron by $R$. purpureum (Pursh) G.Don. The replacement epithet honours Kathleen Anne Kron (1956-), Wake Forest University, who has contributed significantly to our understanding of the evolutionary and systematic relationships of Ericaceae.

\section{Rhododendron menziesii Craven, nom. nov.}

Replaced synonym: Menziesia ferruginea Sm., PI. Icon. Ined. 3 (1791) t. 56.

Note - A new epithet is required as ferrugineum is preempted in Rhododendron by $R$. ferrugineum $L$. The replacement epithet honours Archibald Menzies (1754-1842), the collector of the type material of $M$. ferruginea, itself the type species of Menziesia.

\section{Rhododendron menziesii subsp. glabellum (A.Gray)} Craven, comb. nov.

Basionym: Menziesia glabella A.Gray, Syn. FI. N. Amer., ed. 2 (1878) 39. - Menziesia ferruginea var. glabella (A.Gray) M.Peck (1941) 135. - Menziesia ferruginea subsp. glabella (A.Gray) Calder \& Roy L.Taylor (1965) 1398

8. Rhododendron multiflorum (Maxim.) Craven, comb. nov.

Basionym: Menziesia multiflora Maxim., Mém. Acad. Imp. Sci. Saint-Pétersbourg, Sér. 7, 16, 9 (1871) 11.

\section{Rhododendron multiflorum forma bicolor (Makino) Craven, comb. nov.}

Basionym: Menziesia ciliicalyx Maxim. $\alpha$ bicolor Makino, J. Jap. Bot. 1 (1916) 10. - Menziesia multiflora Maxim. var. bicolor (Makino) Ohwi (1953) 883. - Menziesia lasiophylla Nakai forma bicolor (Makino) Hiyama (1964) 126. - Menziesia multiflora Maxim. forma bicolor (Makino) T.Yamaz. (1993) 13.

10. Rhododendron multiflorum forma brevicalyx (Hiyama) Craven, comb. nov.

Basionym: Menziesia multiflora forma brevicalyx Hiyama, J. Jap. Bot. 39 (1964) 127.

11. Rhododendron multiflorum var. purpureum (Makino) Craven, comb. nov.

Basionym: Menziesia ciliicalyx Maxim. $\beta$ purpurea Makino, J. Jap. Bot. 1 (1916) 10. - Menziesia multiflora Maxim. var. purpurea (Makino) Ohwi (1953) 883.

12. Rhododendron pentandrum (Maxim.) Craven, comb. nov.

Basionym: Menziesia pentandra Maxim., Bull. Acad. Imp. Sci. Saint-Pétersbourg 11 (1867) 431.

13. Rhododendron pilosum (Michx. ex Lam.) Craven, comb. nov.

Basionym: Azalea pilosa Michx. ex Lam., J. Hist. Nat. 1 (1792) 410. — Menziesia pilosa (Michx. ex Lam.) Pers. (1805) 420.

\section{Rhododendron yakushimense (M.Tash. \& H.Hatta)} Craven, comb. nov.

Basionym: Menziesia yakushimensis M.Tash. \& H.Hatta, Bot. Mag. (Tokyo) 99 (1986) 33.

\section{Rhododendron incertae sedis}

Diplarche Hook.f. \& Thomson (1854) 382, t. 11

Note - As discussed above, the position of Diplarche within Rhododendron is uncertain and a formal taxonomic disposition for the following two species is not possible.

\section{Rhododendron chamberlainii Craven, nom. nov.}

Replaced synonym: Diplarche multiflora Hook.f. \& Thomson, Hooker's J. Bot. Kew Gard. Misc. 6 (1854) 383, t. 11A.

Note - A new name is required as the epithet multiflorum is pre-empted in Rhododendron by $R$. multiflorum (Maxim.) Craven (see above). The replacement epithet honours David Franklin Chamberlain (1941-), Royal Botanic Garden, Edinburgh, who has contributed significantly to our understanding of the taxonomy of Rhododendron. 


\section{Rhododendron sophistarum Craven, nom. nov.}

Replaced synonym: Diplarche pauciflora Hook.f. \& Thomson, Hooker's J. Bot. Kew Gard. Misc. 6 (1854) 383, t. 11B.

Note - A new name is required as the epithet pauciflorum is pre-empted in Rhododendron by $R$. pauciflorum King \& Gamble. The new epithet is derived arbitrarily from the Greek, sophistes, master, expert, and is intended to honour those persons who strive to understand the natural world around them, to delve into the intricacies of the species on this planet, and to determine the evolutionary relationships and systematic positions of these species, etc. At a time when such knowledge is increasingly required, due to increasing pressure on natural and seminatural habitats, it is regrettable that the number of investigators is reducing around the world due to inadequate funding by governments.

Acknowledgements Victoria McLeod, Missouri, Jeremy Bruhl, Armidale, and Michelle Hearn, Canberra, are thanked for their cooperation in obtaining copies of certain references for me. Alan Leslie, RHS U.K., provided information on the number of rhododendron cultivars. The directors and curators of the herbaria CANB and MEL are thanked for the opportunity to examine collections in their care.

\section{REFERENCES}

Calder JA, Taylor RL. 1965. New taxa and nomenclatural changes with respect to the flora of the Queen Charlotte Islands, British Columbia. Canadian Journal of Botany 43: 1387-1400.

Chamberlain D, Hyam R, Argent G, Fairweather G, Walter KS. 1996. The genus Rhododendron: its classification and synonymy. Royal Botanic Garden, Edinburgh.

Copeland HF. 1943. A study, anatomical and taxonomic, of the genera of Rhododendroideae. American Midland Naturalist 30: 533-625.

Fang M-Y, Fang R-Z, He M-Y, Hu L-C, Yang H-P, Qin H-N, Ming T-L, Chamberlain DF, Stevens PF, Wallace GD, Anderberg A. 2005. Ericaceae. In: Wu Z, Raven PH, Flora of China 14: 242-517. Science Press, Beijing; Missouri Botanical Garden Press, St. Louis.

Goetsch LA, Eckert AJ, Hall BD. 2005. The molecular systematics of Rhododendron (Ericaceae): A phylogeny based upon RPB2 gene sequences. Systematic Botany 30: 616-626.

Gray A. 1878. Menziesia. Synoptical Flora of North America 2: 39. Ivison, Blakeman, Taylor \& Co., New York; Wesley, London; Weigel, Leipzig.

Handa T, Kita K, Wongsawad P, Kurashige Y, Yukawa T. 2003. Molecular phylogeny as a guide for breeding of ornamentals: the case study of Menziesia and Dendrobium. Acta Horticulturae 612: 155-163.
Handa T, Kita K, Wongsawad P, Kurashige Y, Yukawa T. 2006. Molecular phylogeny-assisted breeding of ornamentals. Journal of Crop Improvement 17: 51-68.

Hiyama K. 1964. Miscellany from Makino Herbarium. The Journal of Japanese Botany 39: 124-128.

Hooker JD, Thomson T. 1854. On Maddenia and Diplarche, new genera of Himalayan plants. Hooker's Journal of Botany and Kew Garden Miscellany 6: 380-384, t. 11, 12.

Kikuchi M. 1962. A new species of the genus Menziesia from Japan. The Journal of Japanese Botany 37: 353-356.

Kita K, Kurashige Y, Yukawa T, Nishimura S, Handa T. 2005. Intergeneric hybridization between Menziesia and Rhododendron based on molecular phylogenetic data. Journal of the Japanese Society for Horticultural Science 74: 51-56.

Kron KA, Judd WS, Stevens PF, Crayn DM, Anderberg AA, Gadek PA, Quinn CJ, Luteyn JL. 2002. Phylogenetic classification of Ericaceae: molecular and morphological evidence. The Botanical Review 68: 335-423.

Kurashige Y, Etoh JI, Handa T, Takayanagi K, Yukawa T. 2001. Sectional relationships in the genus Rhododendron (Ericaceae): evidence from matK and trnK intron sequences. Plant Systematics and Evolution 228: 1-14.

Lamarck MM. 1792. Azalea pilosa. Journal d'Histoire Naturelle 1: 410.

Makino T. 1916. A contribution to the knowledge of the flora of Japan. The Journal of Japanese Botany 1: 9-10.

Maximowicz CJ. 1867. Diagnoses breves plantarum novarum Japoniae et Mandshuriae. Bulletin de I'Academie Imperiale des Sciences de SaintPétersbourg 11: 430-431.

Maximowicz CJ. 1871. Menziesia. Mémoires de l'Académie Impériale des Sciences de Saint-Pétersbourg, Sér. 7, 16, 9: 7-12.

Miquel FAW. 1863. Ericaceae laponicae. Annales Musei Botanici LugdunoBatavi 1: 28-35.

Mochizuki R. 1981. A new hybrid of Menziesia (Ericaceae). The Journal of Phytogeography and Taxonomy 29: 108-109.

Ohwi J. 1953. Menziesia. Flora of Japan: 882-883. Shibundo, Tokyo.

Peck ME. 1941. Combinations proposed in "The higher plants of Oregon". Madroño 6: 133-137.

Persoon CH. 1805. Menziesia. Synopsis Plantarum 1: 419-420.

Smith JE. 1791. Menziesia. Plantarum Icones Hactenus Ineditae 3: t. 56.

Spethmann W. 1987. A new infrageneric classification and phylogenetic trends in the genus Rhododendron (Ericaceae). Plant Systematics and Evolution 157: 9-31.

Stevens PF, Luteyn J, Oliver EGH, Bell TL, Brown EA, Crowden RK, George AS, Jordan GJ, Ladd P, Lemson K, McLean CB, Menadue Y, Pate JS, Stace HM, Weiller CM. 2004. Ericaceae. In: Kubitzki K, The families and genera of vascular plants 6: 145-194. Springer, Berlin \& Heidelberg.

Tashiro M, Hatta H. 1986. Two new species of the genus Menziesia from Japan. The Botanical Magazine, Tokyo 99: 29-36.

Yamazaki T. 1993. Ericaceae. In: Iwatsuki K, Yamazaki T, Boufford DE, Ohba H, Flora of Japan 3: 6-63. Kodansha, Tokyo. 